\title{
The Debt-Equity Ratio Choice: Risk Sharing Instruments, A Viable Alternative
}

\author{
Shamsuddeen Muhammad Ahmad ${ }^{1}$, Wan Ahmad Bin Wan Omar', \\ Mohd Zukime Bin Mat Junoh ${ }^{3}$ \\ Kano State Polytechnic, Kano, Nigeria ${ }^{\text {}}$, University Malaysia Perlis (UNIMAP) ${ }^{2,3}$ \\ shamsudandago@yahoo.com ${ }^{I}$, \\ wanahmad@unimap.edu.my ${ }^{2}$,zukime@unimap.edu.my ${ }^{3}$
}

\begin{abstract}
Evidence has been documented in the literature that the interest based debt financing system is experiencing continuous discomfort. The outcome of the 2008 global financial crisis has further create fresh vigor to the assertion. Also, these authors have submitted that debt and leveraging are the two major causes of financial instability in the present system. This paper claims that the existence of the interest-based debt regime is becoming less acceptable, as excessive debt can affect the whole economic system, even in a developed country like United States. From an economic viewpoint, therefore, by banning interest rate-based contracts and decreeing exchange contracts, Islamic financeinspires risk sharing and prohibits risk transfer, risk shedding, and risk shifting. The paper proposes risk sharing based Islamic financing as a suitable alternative to the interest based debt financing. This study concludes that risk-sharing finance has several benefits, especially its potential to minimize, if not circumvent, the debt prompted financial crises that have beset the world.
\end{abstract}

Keywords : Debt-Equity Ratio; Risk Sharing Instruments; Islamic Finance

\section{A. INTRODUCTION}

Corporate financing decisions are quite intricate processes and present theories can at best clarify only certain aspects of the diversity and intricacy of financing choices (Margaritis, \&Psillaki, 2010). However, Modigliani and Miller (I958) and others have uncovered that the debt-equity choice is intricate by a number of factors other than relative cost. The main benefit of debt financing, relative to equity, is the fact that it results to no dilution in ownership and then in future earnings (Bacha, Mirakhor\& Askari, 20I5). Essentially, there are two major 
The Debt-Equity Ratio Choice: Risk Sharing Instruments,

A Viable Alternative

(Shamsuddeen Muhammad Ahmad' ${ }^{1}$ Wan Ahmad Bin Wan Omar²,

Mohd Zukime Bin Mat Junoh ${ }^{3}$ )

ways in which firms choose to finance their asset, through debt or equity. This can be achieved through bank loans, bonds, account payable and line credit as well as retained earnings and preferred stock (Ross, Westerfield\& Jaffe, 2002). The relationship between debt and equity is usually measured with the debt proportion ratio and represent the capital structure of a firm (Mc Menamin, 1999).

However, it has been documented in the literature that the interest based debt financing system is experiencing continues discomfort. The outcome of the 2008 global financial crisis has further create fresh vigor to the assertion. Also, these studies have submitted that debt and leveraging are the two major causes of financial instability in the present system (Reinhart and Rogoff, 2009). However, in a well-organized capital markets, the dissimilarity between the price of equity and debt should replicate the contrast in risk profile. Likewise, debt financing has positive relationship with risk. Therefore, on equilibrium, a risk neutral firm would get no benefit in switching equity with debt (putting aside the issue of taxes). Hitherto, this may not be true. Since, several crises have revealed that there is a strong inclination, if not an absolute bias, for debt (Bacha, Mirakhor\& Askari, 2015)

A central feature of the interest-based system is that the risks associated with the debt contract are shifted from the creditor to the debtor. The creditor is assured a return irrespective of the result of the business activity of the debtor (Othman, et.al. 2017). More so, this system of risk transfer will empower the rich to become richer and the poor becomes poorer. Thus, constant transfer of risk with interest rate based debt instruments are not helping the mutual well-being. Risk sharing may perhaps provide an effective replacement (Mirakhor,2012). Therefore, the topic of risk management became a matter of interest not only to the business organizations but also to the policy makers (Othman, et.al. 2017). Therefore, it brings to the rise of the need for private firms to understand the risk sharing instruments of Islamic finance to overcome the debt dilemma in their capital structure decision (Bacha, 2017).

\section{B. THEORITICAL}

\section{The Debt-Equity Ratio Choice}

Empirical researches on the debt-equity ratio choice have significantly increased in the wake of the prominent seminal works of Modigliani and Miller (I963). Modigliani and Miller suggested the application of more debt by firms in their CS to maximize value, achieved through high profit, increased share prices and efficiency in management. On the other hand (Jensen \& Meckling, 1976) argued 
that, although debt may generate a higher return to shareholders, it may result in additional agency costs in the form of covenants and monitoring actions. (Myers, 1977) identified two tax advantages two benefits of debt which includes and the reduced agency cost of the free cash flows. Its cost according to him includes bankruptcy costs and increased agency costs when firm credit worthiness is in doubt.

However, capital structure is the combination of long-term sources of funds used by a firm, namely non-current liabilities and equity. Generally, bonds (debt securities) and long-term loans are categorized under non-current liabilities while equity is denoted by preferred and common shares (Keown, Martin, Petty, \& Scott, 2008). Therefore, a firm can select any type of capital structure. When a company issues more bonds, the debt equity ratio will increase. On the other hand, a company that issues more shares decreases its debt-to-equity ratio (Ross, Westerfield, \& Jordan, 1999).

Furthermore (Esperança and Matias, 2005) argues that debt issuance is associated with an increasing risk which should be covered from equity return. A study by Borges et al. (2007) revealed that the key indicators associated to capital structure choices are equity-debt-solvability ratios. As they decide the amount of equity and debt while companies finance their assets independently from respective nature and function, as well as express the ability to pay corresponding debts. Harvey, (2014) affirmed that debt finance played a restraining role for managers and forced them to operate hardy to enhance the company solvency, so increasing the debt ratio can improve the value of the firm. (Hadlock \& James, 2002), (Margaritis \& Psillaki, 2010) and (Berger \&Bonaccorsi di Patti, 2006) had also come to the same conclusion in their empirical studies.

\section{Implications of Excessive Debt}

During the financial crises, everyone looked at debt as a risky instrument (Fong, 2008; 2009). Hence, excessive debt can upset the entire economic system, even in a developed country like United States. Similarly, with respects to business corporations, there is no hesitation that leverage is a cause of tax shielding (Myers, 200I) and that the owner of the company uses it as a strategy to control the decision making process since the company does not have any public shareholding (Baumol, 1965). (Nevertheless, Stone, 2000) stressed that financial crisis is permanently linked with company debt based on his studies of the consequences of financial crisis for company output. 
The Debt-Equity Ratio Choice: Risk Sharing Instruments,

A Viable Alternative

(Shamsuddeen Muhammad Ahmad', Wan Ahmad Bin Wan Omar²,

Mohd Zukime Bin Mat Junoh ${ }^{3}$ )

(Ross eta, 1999) and (Fong, 2008) further contend that the prospect of a firm facing financial torture is great when the firm is over-leveraged. Norita and (Shamsul Nahar, 2004) claim that the debt ratio for financially troubled firms is greater than in vigorous companies. Moreover, (Reinhart and Rogoff, 2009) maintained that all crises of the past have been, at their core, debt crises, irrespective of whether they were categorized as "currency" or "banking" crises. In addition, it is further projected that there are about USD200 trillion value of paper securities in the worldwide economy of which USDI50 trillion are interest ratebased debt instruments (Rogoff, 20I I).

Therefore, to put up with a strong financial structure, managers of corporation need to select a combination of equity and debt in order to lower the weighted average cost of capital. However, by reducing the cost of capital, the value of the company can be maximized, thus, making better return to shareholders and stakeholders (Keown etal., 2005). Nevertheless, sometimes the cost of capital increases as the volume of debt rises. This turn out to be more serious when the cost of capital rises and the value of the firm drops as the level of debt goes up. Therefore, under this situation, the benefit of debt financing is offset by the costs of financial distress, and this results a greater problem of bankruptcy (Ross etal., I999).

\section{The Concept of Risk Sharing in Islamic Finance}

Risk sharing is one of the most significant aspect needed in Islam for the unity of mankind. Basically, Islamic finance is a financial arrangement structured on risk sharing (Othman, et.al. 2017). Islam is a rules-based system in which a grid of given rules administers the socio-economic and political life of the public (Mirakhor and Hamid, 2009). Therefore, abiding by these guidelines makes the people a union of joint support by demanding individuals to share the risks of life (Mirakhor, 2010; Askari, et. al., 2012). Manage financial volatility and to permit consumption smoothing, which is a key result of risk sharing and uplifts the welfare of the parties to the exchange. Thus, the prominence on risk sharing is provide in the holy Qur'anconcerning economic behavior. The Qur'an states that; "they say that indeed al-bay' is like al-riba. But Allah has permitted al-bay' (exchange contract) and has forbidden al-riba (interest-based debt contract)" $(2: 275)$.

Furthermore, as the Qur'an for bids all debt contracts based on interest, it concurrently proclaims a substitute. However, the alternative to debt-based contracts is al-bay'-which means, a mutual exchange in which one package of property rights is exchanged for another, hence allowing both parties involve to 
share all risks involved. It also permits both parties to an exchange to ease the risk of income.

The Qur'an further recommends that risk sharing, alongside with other approved social rules such as cooperation (Qur'an, 5:2), and encourages human cohesion by taking humanity closer to unity, which in itself is a result of Islam's principal axiom, i.e. the unity of the creator. However, an Islamic philosophic axiom proclaims that from one creator only one creation can issue. The Qur'anit self clearly states:

"Neither your creation (was) nor your resurrection (will be) other than as one united soul" (Qur'an, 3I:28)

Moreover, in a sequence of verses, the Qur'an urges people to take individual and collective actions to attain societal unity and cohesion and the same time try to reserve and keep collectivity from all elements of disunity (for example, Qur'an 3:I03). So, encouraging maximum risk sharing is, unarguably, the ultimate objective of Islamic finance. It is for this reason that scholars consider profit-loss sharing and equity participation as first best instruments of risk sharing (Mirakhor and Iqbal, 2007). In this manner, social integration is enhanced.

\section{Islamic Finance is Equity-Based and Risk-Sharing Finance}

The basic principle of Islamic finance is the avoidance of interest and all contracts based on interest. Thus, Qur'an considers charging of interest as a serious violation of Islamic rule (see Qur'an 2:276), which is reflected as an act of injustice. However, full comprehension of the essence of these verses which prescribed that interest based debt transactions need to be substituted by contracts of exchange necessitates an analysis of the particularities of the two contracts (Askari et. al., 2012). While stressing the advantage of a system mainly based on equity financing, (Einaudi, 2006) submit "A modern market economy needs financial contracts. In theory these could all take equity form, and if they did economies would suffer less macroeconomic instability".

(Likewise, Taleb, 2012) maintained that for a financial system to escape fragility and the happening of black swans, the system requires to get free of debt financing and choose equity financing. Besides, with equity financing all participants will partake extra skinin the game. This means that, no one would be in a situation to have the upside without sharing the downside, mostly when others may be injured. This would unavoidably oblige and even reduce moral hazards and agency problems; features that will continuously be pervasive in a debt based system (see also Hellwig, 1998) 
The Debt-Equity Ratio Choice: Risk Sharing Instruments,

A Viable Alternative

(Shamsuddeen Muhammad Ahmad' ${ }^{1}$ Wan Ahmad Bin Wan Omar²,

Mohd Zukime Bin Mat Junoh ${ }^{3}$ )

Again, Stiglitz (1989) compared the structures of equity and debt contracts and claims that from the viewpoint of the entrepreneur, equity possessed two advantages. Firstly, the risk of the project is shared with the provider of capital, and there is no fixed commitment for paying back the funds. Hence, in a situation of failure, payments to the capital provider are adjourned. Moreover, the company will not be found bankrupt, and will not be obligated to put in place any measures to plank off bankruptcy. Likewise, looking at it from a social point of view, equity possessed a distinct advantage: since risks are jointly shared between the entrepreneur and the provider of the capital, it indicates that firm will not usually cut production than it would with debt finance, especially when the economy experienced a downturn (see also Greenwald and Stiglitz, I986).

Therefore, by prohibiting interest rate-based contracts and decreeing contracts based on exchange and mutual benefits, the Qur'an inspires risk sharing and forbids risk transfer, risk flaking, and risk shifting. However, under a classic risk-sharing plan such as equity finance, the parties in the contracts share the risk and also the return of a contract. In contrast, under an interest rate-based debt contract the risk involved the business operation is shifted from the sponsor to the borrower, through which the financier holding not only the rights to claim the principal and interest but as well any collateral that stand as guarantee to the financing agreement. Furthermore, under a risk sharing plan, such as equity arrangement, the investment is made on a profitable trade and production activities, also the revenues attached to the business are not known at the beginning of the investment, and are as a result, a random variable resulting in equities to be a risky assets.

\section{Risk-Sharing instruments and the debt-equity choice}

In corporate finance, there is a trade-off between debt and equity financing. However, debt is considered cheaper but more risky than equity. Equity, though assumed to be safer, is not only more costly but can result undesirable ownership dilution (Bacha, 20I7). Generally, due to this trade-off, companies are oftendisposed to use debt financing. (Jensen and Meckling, 1976) have also argued that, the debt-equity choice is intricate by a number of factors other than relative cost. The main benefit of debt financing over equity, is the fact that it results to no erosion in ownership and so in future earnings. Thus, firms attributed to concentrated ownership may likely have higher financial leverage. As such, companies inclined to finance low-risk, high return projects with debt and high-risk projects with equity (Bacha, Mirakhor\& Askari, 2015). Incidentally, the problem 
with equity is that since it is assume to be everlasting, the dilution in ownership is also perpetual. By contrast, debt is terminal

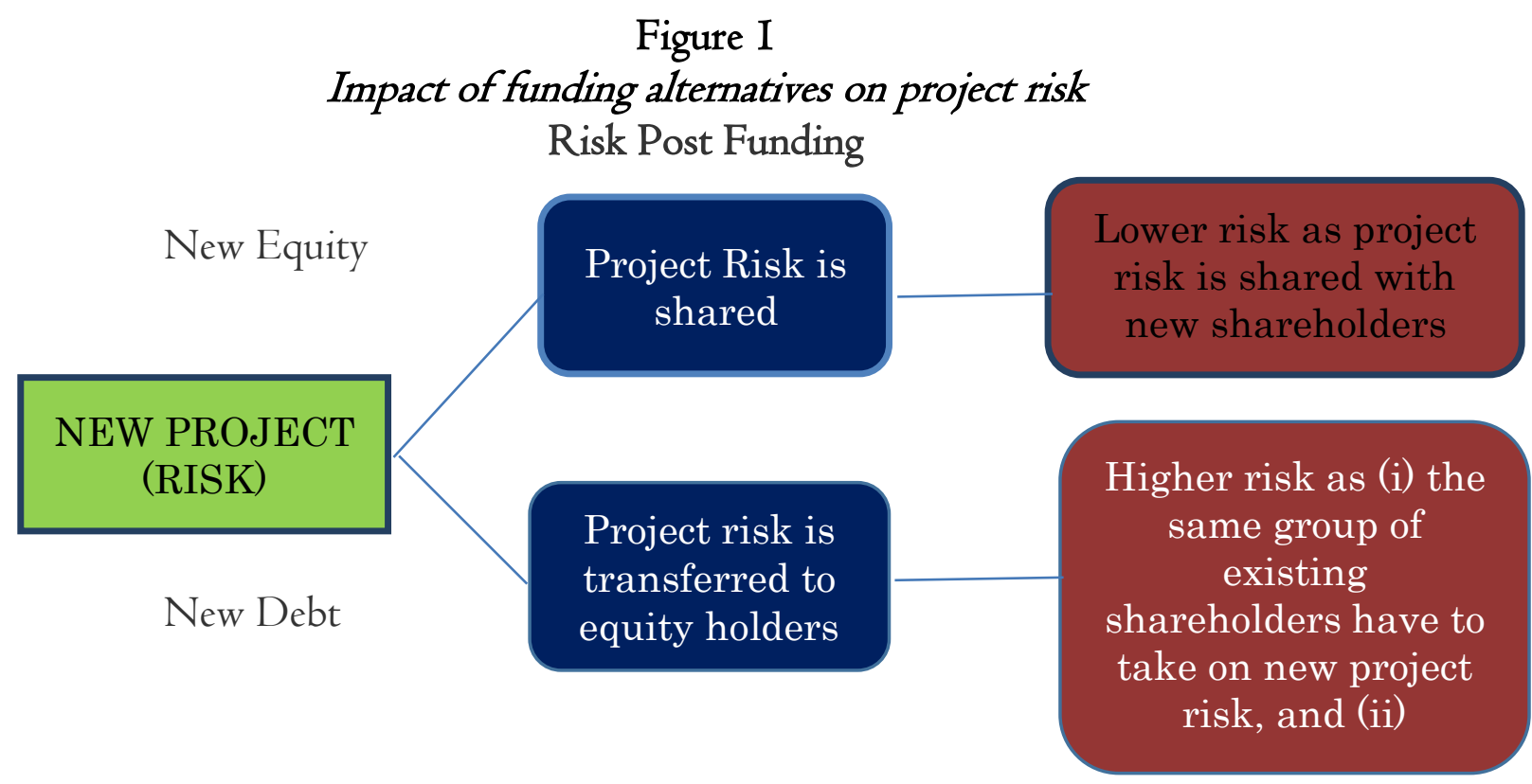

Moreover, (Bacha,Mirakhor\&Askari, 2015) identified five motives why companies are enticed to debt financing. the financier, for instance, he may prefer debt over equity because: (i) the risk of the business is not shared with him; (ii) he can also make a claim on the business risk though not involved; (iii) irrespective of the performance of the borrower he is 'assured' of a fixed return; and (iv) whereas equity is persistent in claim and everlasting in time, debt is fixed in claim and time.

On the other hand, for risk-sharing instrument to be workable, it should deliver the benefits of debt without the attendant leverage, be cost-effective, and be striking to both potential borrowers and financiers (Bacha, 2017). It is expected also be practical and objectively simple. In addition, investors should be able to simply comprehend how the instrument works and it's pricing. If the instrument can possessed structures of the current market-traded instruments, it can easily attract market acceptance. Besides, gain Muslims acceptance, the instrument must conform with Shari ah requirements (Bacha, Mirakhor\& Askari, 20I5)

\section{Potential of Risk-Sharing Instruments for corporate financing}

Prior studies have identified the potentiality of risk-sharing instruments to neutralize some of the elements that result in debt to be attractive. Accordingly 
The Debt-Equity Ratio Choice: Risk Sharing Instruments,

A Viable Alternative

(Shamsuddeen Muhammad Ahmad', Wan Ahmad Bin Wan Omar'2,

Mohd Zukime Bin Mat Junoh ${ }^{3}$ )

these instruments must offer the benefits of debt without the associated leverage, be cost-effective and also be attractive to both prospective borrowers and financiers (Bacha, 2017).They should also be practical and demonstrably simple. However, (Bacha, Mirakhor\& Askari, 2015) suggested two generic conditions where risksharing instruments can be used to finance a project, i.e. to finance a revenue generating project and non-revenue-generating project.

\section{Funding revenue generating projects}

In a situation where, RS instrument is utilized to finance a revenue-generating asset, the risk sharing should be in line with the generated income by the asset. This means that, the revenue to the financier will be in direct connection to the income generated by the project. Under such condition, it is similar to equity instrument. Nevertheless, different to a new issue of common stock, which would have a right on all the current assets together with the new project, this RS instrument would therefore, have a claim only on the earnings of the new project.

Meanwhile, the original contract can be a modified mudarabahor musharakahput together with a wakalah. Also, the instrument have a fixed term and will remain terminal. However, the term will depend on the following factors:

I) The economic life of the venture or underlying asset

2) Cash flows/earnings generated

3) Profit-sharing ratio (PSR); and

4) Required return given the riskiness of the project.

Furthermore, the term would be formulated in such a way that for a certain PSR and required return, the investor may expect his initial investment back plus his profit. This instrument can be listed and traded on secondary markets. However, secondary trading offers a lot of benefits, such as greater liquidity, that will entice a wider range of investors.

\section{METHODOLOGY}

In essence, the use of small denominations may attract small retailers and this can be promoted if dealings in these instruments can as well be managed through banks and establishments such as the post office. Moreover, this will allow investors especially from rural areas to partake with their minor savings. For instance, a potential investor from rural community who is interested can purchase at existing prices and retail via his local bank or post office with the transaction being affected at the day's closing price much like mutual funds. 
Fundamentally, pricing ought to be in line with the rationality of valuation in finance. That is value should equal the present-value of future expected cash flows from the investment. Basically:

Price $=\sum_{t=1}^{n} \frac{\hat{\mathrm{e}} \cdot P S R}{(1+K)^{t}}$

Where $\hat{\mathrm{e}}_{t}$ stand for the projected net earnings in year t, PSR represents the profit sharing ratio, and $k$ is the required return/profit rate. Therefore, the expected net earnings can be determined based on the parameters agreed to and the forecasted revenue/earnings.

As an alternative, after-tax net cash flows can as well be used in place of êt. Aftertax net cash flows start with net profit and adjust for non-cash expenses such as depreciation, amortizations, provisions etc., and changes in net working capital, capital outlays and other cash flows. The adjustment for non-cash expenses effectively neutralizes accounting related biases. The profit-sharing ratio should be fix in a way that the initial investment $(I$ is recoverable given the required profit rate and term. PSR, therefore, is a function of the term, average expected earnings, initial investment and the required profit rate:

$P S R=f(I, T, \bar{e}, k)$

Where $\bar{e}$ is the average of expected annual earnings. Besides, the appropriate term should vary according to the project being financed. Generically, the term can be determined as

Term $=\left[\frac{I(1+k)}{\overline{\mathrm{e}}_{t} \cdot P S R}\right] \leq$ economiclife

The desired profit rate $k$ is the also not known. While trading, $k$ should be a market-derived rate, just like the desired return for stocks. However, considering the terminal nature the profit/risk sharing, the desired profit should be lesser than the expensesof the issuing equity but greater than cost of debt. Since the rightsof the instrument are directly on the earnings of the specific asset/orproject, organized by the company's other responsibilities, the desired returnmay virtually be dependent on the instabilities of the asset's earnings. Additionally, as a markettraded instrument, the desired return isessentially market determined. Thus, for a particular set of anticipated future earnings, term and PSR, the desired return will be implied in its market price:

$\%=\left[\frac{\overline{\mathrm{e}}_{t}{ }_{t} P S R}{\text { Price }}\right] \cdot 100$

Percentage $k$, or holding period return, will comprise both the returns from profits received and capital gains; $k$ then would be reliant on the instability of anticipated 
The Debt-Equity Ratio Choice: Risk Sharing Instruments,

A Viable Alternative

(Shamsuddeen Muhammad Ahmad', Wan Ahmad Bin Wan Omar'2,

Mohd Zukime Bin Mat Junoh ${ }^{3}$ )

earnings ( $\hat{e}), P S R$ and market factors. Indicative $k$ can be derived from the ROA (return on assets) of similar projects/industries. This means, the returns of a firm in the same industry as that of the project can be unlevered to estimate $k$.

\section{RESULS AND DISCUSSION}

Profit sharing can only works where a project make a profit. However, in a situation where a project or asset is a cost center, other plans could be applied, such as ijarah (leasing) contract. More so, to evade fixity the ijarah payments, that is normally amortizing, can take in an amount benchmarked on industry performance. This benchmark could be, for instance, the average industry ROA or the average ROA of the top 5 players in the given industry. Thus, the ijarah payment could be derived as:

Ijarah payment $=I j t=[$ amortization amount for principal + rent $+(0.3 \cdot$ industry $R O A)]$

All the three items can be ascertained so that based on the desired profit rate, the financier can anticipate to recuperate the investment. Also, under ijarahbased instrument, the benefit to the 'borrowing' company over an absolute debtbased bond finance will be that the company may be able to miss payments in bad times, but with the stipulation that either the term is amplified or 'missed' payments are made collective. This indicates that there is no fixity. Therefore the amount to be receive by the investor for the duration cannot be foretell. Besides, the anticipated cash-flows in the form of ijarah payments from the investment can be ascertained. Given these expected cash flows, the price of the instrument and the desired return can be:

$$
\begin{array}{r}
\text { Price }=\sum_{n=1}^{t} \frac{I_{j t}}{(1+K)^{t}} \ldots \ldots \ldots \ldots \ldots \ldots . . . . . . . . . .
\end{array}
$$

The equilibrium 'price' would be where the NPV is zero, or:Price- Initial investment $=0$

In any given year, the holding period return would be:

$\% k=\left[\frac{I_{j t}}{\text { Price }}\right] \cdot 100+\left(\frac{p_{1}-p_{0}}{p_{0}}\right) \cdot 100$.

About the example of the previous modified mudarabah instrument, market trading would entail that overall returns will be a mixture of the received ijarah payments and capital gains/losses. Therefore, there are two fundamentals that ensure fixity is evaded. First is the benchmark within the industry ROA and, second, the capital 
gains/losses. In addition to avoiding fixity, the benchmark portion of the ijarahpayment has the advantage of keeping the 'borrowing' firm's management benchmarked to the best in the industry.

\section{E. CONCLUSION}

The study aims at arguing that the current interest-based debt financing regime is characteristically unsteady and crisis prone. This has been confirmed by previous studies who claimed that debt and leveraging are the major causes of financial volatility in the present system. In contrast, Islamic finance, through its prominence on risk-sharing for the fulfillment of socio-economic goals based on the objectives of Shariah, offers the discipline that augments the outlook of consolidating the connection between finance and the real economy, therefore contributing towards overall financial stability.

Moreover, Islamurges people to take individual and collective actions to attain social unity and cohesion and at the same time try to preserve and keep collectivity from all elements of disunity. Therefore, supporting maximum risk sharing is, assuredly, the ultimate objective of Islamic finance. It is for this reason that Islamic scholars consider profit-loss sharing and equity participation as first best instruments of risk sharing (Mirakhor and Iqbal, 2007). In this manner, social integration is enhanced. This study contributes to the existing literature by linking Islamic finance and corporate finance as well as highlighting the numerous benefits of risk-sharing finance, especially its potential to minimize, if not avoid, the debtinduced financial crises that have plagued the world.

\section{REFERENCES}

Askari, H, Iqbal, Z, Krichene, N. Mirakhor, A. (2012). "Risk Sharing in Finance: The Islamic Finance Alternative." Singapore: John Wiley and Sons (Asia). Bacha, O. I., (2017). Overcoming the debt dilemma with risk-sharing instruments. In Islamic Commercial Law Report, 20I7; an Annual Publication Assessing the Key Issues and Global Trends in Islamic Capital Markets. (pp. 90-9I). Isra\&Thomson Reuters.

Bacha, O. I., Mirakhor, A., \& Askari, H. (2015). Risk sharing in corporate and public finance: the contribution of Islamic finance.

Baumol, W. J. (1965). Fordham University Press. In Myers, S. C. (200I). Capital structure. Journal of Economic Perspectives, I5(2), 8I-I02. 
The Debt-Equity Ratio Choice: Risk Sharing Instruments,

A Viable Alternative

(Shamsuddeen Muhammad Ahmad', Wan Ahmad Bin Wan Omar'2,

Mohd Zukime Bin Mat Junoh ${ }^{3}$ )

Berger, A. N., \& Bonaccorsi di Patti, E. (2006). Capital structure and firm performance: A new approach to testing agency theory and an application to the banking industry. Journal of Banking and Finance, 304), I065-I I02.

Borges, A., Rodrigues, A., \&Morgado, J. (2007). Contabilidade e finanças para a gestão, Lisboa, $3^{\circ}$ Edição: ÁreasEditora

Einaudi, L. (2006). First published as "Debiti”. In La ReformaSociale XLI. XLV (I). January 1934. "Debts". In Selected Economic Essays, edited by L. Einaudi, I I2- I23. Basingstoke, Hampshire: Palgrave Macmillan

Esperança, J., \& Matias, F. (2005). FinançasEmpresariais, Lisboa, Dom Quixote

Fong, K. (2008, November 3). On safer ground. TheEdge Malaysia, 66-67.

Fong, K. (2009, March 9). Oil money keeping Gulf economies afloat. TheEdge Malaysia, 67.

Greenwald, B. C., \& Stiglitz, J. E. (I986). Externalities in economies with imperfect information and incomplete markets. The quarterly journal of economics, $\operatorname{IOI}(2), 229-264$.

Hadlock, C. J., \& James, C. M. (2002). Do banks provide financial slack? Journal of Finance, 573), I383-1419

Harvey, J. T. (20I4). Student loan debt crisis. . Forbes Magazine.

Hellwig, M. (1998). "Banks, Markets, and Allocation on Risks in an Economy". Journal of Institutional and Theoretical Economics (JITE), vol.I54, no.I, pp.328-345.

Jensen, M. C., \&Meckling, W. H. (1976). Theory of the firm: Managerial behavior, agency costs and ownership structure. Journal of financial economics, 3(4), 305-360.

Keown, A. J. (2008). John D. Martin. J. William Petty and David F. Scott Jr. Financial Management: Principles and Applications, Edisi X. United Stated of America: Pearson Education.

Keown, A.J., Martin, J.D., Patty, J.W., \& Scott, D.F. (2008). Financial Management: Principles and Application, IOth edition, Pearson Prentice Hall

Margaritis, D., \&Psillaki, M. (20I0). Capital structure, equity ownership and firm performance. Journal of banking \& finance, 34(3), 62I-632.

McMenamin,J. (1999), "Financial Management". Bath, the Bath Press. 
Mirakhor, A. (2010). (2010). "Whither Islamic Finance? Risk Sharing in an Age of Crises". Paper presented at the Inaugural Securities Commission Malaysia (SC) - Oxford Centre for Islamic Studies (OCIS) Roundtable. "Developing a Scientific Methodology on Shariah Governance for Positioning Islamic Finance Globally”March I5, 2010.

Mirakhor, A. (2012). Islamic finance, risk sharing and macroeconomic policies. Munich Personal RePEc Archive (MPRA), No. 4706I.

Mirakhor, A. and I. S. Hamid (2009). "Islam and Development". New York: Global Scholarly Publications.

Mirakhor, A., \& Zaidi, I. (2007). Profit-and-loss sharing contracts in Islamic finance. Handbook of Islamic banking, 49, 25-37.

Modigliani, F., \& Miller, M. H. (I958). The cost of capital, corporation finance and the theory of investment. The American economic review, 48(3), 26I297.

Modigliani, F., \& Miller, M. H. (I963). Corporate income taxes and the cost of capital: a correction. The American economic review, 53(3), 433-443.

Myers, S. C. (I977). Determinants of corporate borrowing. Journal of financial economics, 5(2), I47-I75.

Myers, S. C. (200I). Capital structure. Journal of Economic Perspectives, I5(2), $8 \mathrm{I}-\mathrm{IO} 2$

Norita, M. N., \& Shamsul-Nahar, A. (2004). Voluntary disclosure and corporate governance among financially distressed firms in Malaysia. FRRaG: Theelectronic journal of the Accounting Standards Interest Group of AFAANZ, 3(I). Retrieved November I5, 2018, from http://www.business.curtin.edu.

Othman, A., Sari, N. M., Alhabshi, S. O., \&Mirakhor, A. (2017). Risk Transfer, Risk Sharing, and Islamic Finance. In Macroeconomic Policy and Islamic Finance in Malaysia (pp. 2I-35). Palgrave Macmillan, New York.

Reinhart, C. and K. Rogoff (2009). "This Time Is Different: Eight Centuries of Financial Folly". Princeton University Press.

Reinhart, C. M., \& Rogoff, K. S. (2009). The aftermath of financial crises. American Economic Review, 992 2), 466-72.

Rogoff, K. S. (20II). Global imbalances without tears. Project Syndicate, 20I I-3I.

Ross, S. A., Westerfield, R. W., \& Jaffe, J. (2002). Corporate Finance, 6 "'Edition.

Ross, S. A., Westerfield, R. W., \& Jordan, B. D. (I999). Essentials of corporate 
The Debt-Equity Ratio Choice: Risk Sharing Instruments,

A Viable Alternative

(Shamsuddeen Muhammad Ahmad', Wan Ahmad Bin Wan Omar'2,

Mohd Zukime Bin Mat Junoh ${ }^{3}$ )

finance. United States: Irwin McGraw-Hill

Ross, S. A., Westerfield, R., \& Jordan, B. D. (1999). Finanseprzedsiębiorstw. Dom Wydawniczy ABC.

Suryanto, T., Purnamasari, F., \& Kurniawan, M. (2018). Tax Revenue and

Disparity: How to Improvement Income Inequality in Islamic Perspective. Asian Journal of Social Sciences and Management Studies, 5(2), 65-7I.

Stiglitz, J.E. (1989), Financial Markets and Development, Oxford Review of Economic Policy, vol. 5, no. 4.

Stone, M. R. (2000). The corporate sector dynamics of systematic financial crisis. IMF Working Paper. Retrieved April 20, 2009, from http://www.imf.org/external/pubs/ft / wp / 2000 /wp00I I4.pdf.

Taleb, N. N., \& Martin, G. A. (20I2). How to prevent other financial crises. SAIS Review of International Affaits, 32(I), 49-60. 